\title{
The Patriotism Education under the Perspective of Globalization
}

\section{Chuntao Zhou}

\author{
Jilin Agricultural University, International Education \\ And exchange college, Jilin, Changchun130118 \\ hunter2011@foxmail.com
}

\begin{abstract}
Keywords: The era of globalization, Patriotic education, Chance, Challenge.
\end{abstract}
\begin{abstract}
Globalization is an important feature of the world today. With the further development of globalization, countries and between countries, between area and area, area and the area of contact between the increasingly close, no country in the world and regions can be detached from the world and independent development. Globalization on every aspect of people's lives have had a profound effect on. Patriotism is not exceptional also, given the new connotation of the times of globalization. At the same time the patriotic education in the age of globalization has been a great shock and challenge: the impact of state sovereignty, national culture identity, has shaken the weakened consciousness of citizenship. In addition to the patriotic education, globalization brings opportunities : rich patriotism education form, broaden the content of education in patriotism. In the full analysis of the era of globalization to patriotism education opportunities and challenges under the premise, to inspire patriotism, patriotic education we must improve the patriotic education of the timeliness, targeted, strengthening patriotism education and open sex, reflect patriotism education national. Finally, emphasize on citizen's national education, traditional culture education and how to enrich the patriotism education.
\end{abstract}

\section{Introduction}

The globalization has effected on patriotism education realistically and deeply. With the development of globalization, the connections between all of countries has been frequently, therefore, international events can not been resolved with the single effects of any country. So that, person's insight and thought also need to follow the main stream of social development as well as patriotism education. In globalization era, patriotism education is an essential mental power to national unity, social harmony and state-building. What connotation patriotism education as an new course should involve under the globalization? In the era of development at top speed and interinfiltration, all of those effectiveness, pertinence, epochal character, national character in patriotism education should be concerned deeply. It is the first task for the patriotism education under the development of globalization. By carrying out patriotism education to the residents, advancing their identity in national civilization, strengthening their national self-confidence and national self-pride, strengthening national cohesion force we let them be able to work hard in unity so as to build the socialism and harmonious society together. It is a question that patriotism education must answer and study about how to improve resident's patriotic awareness. Based on the thinking of all these questions, we try to explore the topic of On the Patriotism Education under the Perspective of Globalization in this paper.

\section{The Necessity and Connotation of Patriotism Education}

In the era of globalization, it is not only necessary for us to pay attention to the important meanings of patriotism education, but also to pay attention the new era connotations of patriotism education under the globalization. From both the content and the important meaning we learn the patriotism education in the era of globalization.

New Connotation of Patriotism Education in the Era of Globalization. Patriotism education has different characteristics and connotations in different historical periods. In the era of 
globalization, it is necessary to understand the new connotation of patriotism education in the era of globalization if we explore how to do better to carry out the patriotism education and advance the epochal character and the pertinence of patriotism education. Therefore, we discuss the new connotation of patriotism education from state-building, national development and other points in in the following contents of this paper.

(1) The Patriotism Education should Rises to the Movement from Emotion in the Point of State-building. Practical educations of patriotism and emotional education about the patriotism are two important types of the patriotism education. Emotional education of patriotism is realized by basic theory education, traditional virtue education and the explanation and the publicity of basic requests and others in socialism, and we let the residents establish the right patriotism view and conduct them to put the view into effects.

(2) The Patriotism Education should Be Based on the National Character in Racial and National Development. The exclusiveness of patriotism indicates that the patriotism emotions are different according to different races and nations, and people have deep emotion for their own race and nation. Therefore, the patriotism education must be based on the excellent traditional civilizations of their own race, and explore racial characteristics of their own race, and seek the traditional education resources that apply to their own race. If we had done that, the excellent racial civilizations of our nation would advance and develop better, and the respect and the pride of our own race would be re-built.

\section{The Policies of the Patriotism Education in the Era of the Globalization}

Strengthen the Education of National Condition and Cultivate the Simple Patriotic Emotion. The best direction and simplest goal of the patriotic emotion is to devote the nation's land and the public, and to concern about national condition. The simple patriotic emotion is the base and premiss to cultivate the patriotism better. Therefore, we must strengthen the education of national condition and cultivate the simple patriotic emotion.

(1) Learn National Histories and Devote to the Nation's Land. If we want to carry out the patriotism education among the residents, advancing national spirit and strengthening national unity are the important tasks all the time. Chinese nation is a race with several thousands history. For the patriotism education we should fully use historical culture resources, absorb nutrition from Chinese historical civilization, enrich the content of patriotism. Strengthening historical culture education can not only let the public learn excellent traditional cultures of their own nation systematically and statewide, but also can strengthen the national self-pride and self-confidence of the public with continuing to advance national spirit.

(2) Facing to the National Condition directly, Insist on the Common Ideal firmly. Our nation is a unified multi-ethnic country, if the lack of common ideal, the fading of social faith, every person always do for himself of his group, do not care each other, so that, the society never will be harmonious and coexistence, even to reach the common ideal of socialism. Therefore, the public need not only to understand the building of socialism with Chinese characteristics in theory. The party' s goal in this stage is to build our nation to socialist modern country, which is prosperous and strong democratic 、 civilized and harmonious. It also is the common ideal to all of our races in preliminary stage of socialism. It also need to overcomes all kinds of difficulty during the course of realizing the ideal. I believe in that the renaissance will come and the ideal will be true through common struggles of all of our race and the insistence of faith and ideal.

(3) Devote to Our Own Nation and the People, and Strengthen the National Unity. Devote to Our Own Nation and the Public, and Insist in Doing Service for the People. Devoting to the nation and the public are also basic request of socialism to every civilian, and they are also the duty and responsibility which every civilian should fulfill. It is not easy to carry out the thought of doing service for people in civilians statewide. If we want to break the abstractness of theory education, we should take the example of education effectively, fully make use of the effects of leading role. The example education is more vivid, more impressive and more close to people's lives. 
Strengthen the National Unity, and Object to the National Separation. In the era of globalization, the nation as an international behavioral agent has made the racial problems and racial conflicts at home be increased, has made the international social organizations at oversea be increased. We must strengthen the national unity and the object national separation to guarantee the development of the nation healthily and stably in the wave of the globalization. It is also an important content for the patriotism education so as to strengthen the national unity and safeguard the national reunification. It is also a patriotic act that the patriots will put into practice.

Inherit the Traditional National Cultures, and Promote the Identity of the National Cultures. In the era of globalization, the communications between Chinese cultures and foreign cultures not only promote the rapid development of socialistic culture undertakings in our nation, but also put our excellent traditional cultures into crises. Therefore, we must strengthen the patriotism education, protect and improve the national traditional cultures, and promote the identity of racial cultures.

Inherit the Essences of the National Cultures, and Improve the Traditional Cultures. (1) Explore and Discover the Essences of National Cultures, and Keep the Advance of the National Cultures. At present, it is an important task for building the mental civilization in our nation. And it explores and discovers the essences of the national cultures. In the era of the globalization, the communications and the conflicts between the cultures of all of the nations worldwide have caused that the borders between the cultures of all the nations worldwide have been indistinct. Therefore, in the era of the globalization, we should work hard to explore and discover the essences of the national cultures so as to develop and promote us if we want to maintain the development of traditional national cultures, highlight the characteristics of own national cultures and remain the exclusiveness of own national cultures.

(2) Strengthen the Protection of Traditional Cultures. Inherit the national cultures requires the civilians to maintain the development and the innovation of own national cultures consciously. In order to inherit national cultures better, inherit and develop our national cultures better, promote the identity of national cultures, our nation has done a lot of effects in all aspects. Strengthening the protection of the traditional cultures will not only make dedications to the sustainable development of long historical cultures of Chinese nation so as to let it be different from other cultures, but also make dedications to strengthen civilian's further learning and understanding in national cultures so as to promote the civilian's identity in national cultures. Accordingly, strengthen the national unity, stimulate the passion for the nation.

Absorb the Advanced Foreign Cultures, and Enrich the Contents of National Cultures. The era of globalization is the era of advanced information technology and modern means of transport. They break through the natural time and space limit. In the worldwide, the liberty of information communications, the liberty of people's flows, the liberty of interpersonal interactions, all of those have caused the world to shrink uncessing. The power of globalization worldwide has been changing the culture production and communication, consumption model and structure so that all cultural natures have been expressing complicated and unprecedented. The globalization expands the space of the communication between China and foreign nation and the private convenient platform for extensive communications. Therefore, if we want to preserve the cultural competitive power, we must pay attention to the absorbing and reference of advanced foreign cultures, and then expand our cultures.

\section{Conclusion}

Based on the principle of seeking trues from the facts, according to the practical condition of globalization, we analyze the chances and the challenges of patriotism education at present, and aiming at a series of questions of patriotism education we explore the policies in the paper. So we conclude that based on grasping the cultivation of civilian's simple patriotic emotionthe patriotism education in the era of globalization we further conduct the civilians learn socialism rightly, and unify devoting the party and devoting the socialism organically. Therefore, it can provide certain references for the patriotism education under the perspective of globalization. However, we do not 
further explore the questions which involves how to innovate the methods of patriotism education in the era of globalization. I wish the scholar in this filed could make further exploration afterwards so as to complete the lack about this aspect in the paper.

\section{References}

[1] W.G. Qiu. On the Goal and Innovation of Patriotism Education. Ideological and Political Education.2010(2).

[2] J.F. Guo, Liu Haiying. On the University Student Education of National Awareness. Ideological Education Research.2009.12(12).

[3] F. Liu. On the Characteristics of Times and the Essential Requests of the Contemporary. Ideological and Political Education.2009(12).

[4] Y.L. Yang. Cultural Identity: The Strategic Projects of Patriotism Education. Ideological and Political Education. 2009(11). 